\title{
ASSESSMENT OF THE QUALITY OF ARABICA COFFEE BEANS FROM THREE PROCESSING METHODS AND TWO TYPES OF PACKAGING MATERIALS**
}

\author{
OKKY SETYAWATI DHARMAPUTRA*, SANTI AMBARWATI, INA RETNOWATI AND \\ NIJMA NURFADILA
}

Laboratory of Phytopathology, SEAMEO BIOTROP, Bogor 16134, Indonesia

Received 14 January 2020/Accepted 27 April 2020

\begin{abstract}
In Southeast Asia, Indonesia is the second highest producing country of coffee beans after Vietnam. Consequently, Indonesia competes with other countries in producing good quality coffee beans. However, not many people have sufficient skills in tackling problems related to the postharvest handling of coffee beans. The objective of this study was to assess the quality of Arabica coffee (Coffea arabica) beans in terms of moisture content, fungal infection (especially ochratoxin A or OTA producing fungi), OTA contamination, and the taste of the coffee during storage. The three processing methods used were dry, wet, and semi-wet methods. The beans were packed using two types of packaging materials, i.e., Kantong Semar high gas barrier and polypropylene bags $(4 \mathrm{~kg} / \mathrm{bag})$. They were then stored under warehouse conditions for 4 months of storage. The moisture content of coffee beans processed using the three methods and packed using polypropylene bags was higher than that of coffee beans packed using Kantong Semar high gas barrier; however, it was still lower than the safe moisture content for coffee determined by the Indonesian National Standard $(12.5 \%)$. Aspergillus niger was found in coffee processed using the three methods and packed using a Kantong Semar high gas barrier. Its population was relatively low $(<0.1 \times 10 \mathrm{cfu} / \mathrm{g}$ wet basis). Aspergillus ochraceus was found in coffee processed using dry and wet methods at the beginning of storage. Its population was also relatively low $(<0.3 \times 10 \mathrm{cfu} / \mathrm{g}$ w.b. OTA content was not detected in all coffee samples, because it was lower than the detection limit of the instrument used $(<1.85 \mathrm{ppb})$. At the beginning of the storage, all coffee samples were dominated by yeast with the population of $1.9 \times 10^{2}-1.2 \times 10^{3} \mathrm{cfu} / \mathrm{g}$ w.b. The taste of coffee in various treatments during 4 months of storage was still above the total standard score for specialty grade $\geq 80$. The highest total score (84) was found in coffee beans processed using a dry method and packed in Kantong Semar high gas barrier. The three processing methods and the two types of packaging materials can be used to maintain the quality of coffee beans for 4 months of storage.
\end{abstract}

Keywords: Arabica coffee beans, processing methods, quality, types of packaging materials

\section{INTRODUCTION}

Around 70 countries worldwide are coffee bean producers, with the overwhelming majority of the supply coming from developing countries like Brazil, Vietnam, Colombia, Indonesia, and Ethiopia (Walton 2018). Indonesia is the fourth largest producer in the world and the second largest in Southeast Asia after Vietnam. Two

\footnotetext{
"Corresponding author, email: okky@biotrop.org

*This paper was presented at the International

Conference Science Based Ingredients: The Future for

Food in Asia; Jakarta 3 - 5 October 2018, Indonesia
}

kinds of coffee renowned in Indonesia are Robusta coffee (Coffea canephora) and Arabica coffee (C. arabica). Robusta and Arabica coffee contribute around $83 \%$ and $17 \%$, respectively, to the total coffee production in Indonesia (GAEKI 2018). As one of the largest producers, Indonesia competes with other countries in producing good quality coffee beans. Hence, stringent rules must be imposed to maintain the quality of exported beans. However, not many people have sufficient skills in tackling problems related to the postharvest handling of coffee beans. 
In Indonesia, there are three processing methods of coffee beans, i.e., dry, wet, and semi-wet processing (Kementerian Pertanian RI 2012). Dry (natural) processing method is a process which consisted of sun-drying the harvested ripe coffee berries for 14 days until the moisture content attained $\pm 10 \%$, followed by shelling of the husks and hulls of the coffee berries. Wet (fully washed) processing method is a process which consisted of shelling the husks of ripe coffee berries to become wet green beans with hulls. The wet green beans were then fermented for one night and washed using water to eliminate the mucus, followed by sun-drying for 7 days until reaching moisture content of $\pm 10 \%$ (dried green beans). The hulls of the beans were then shelled (green beans). Semi-wet (semi-washed) processing method is a process which consisted of shelling the husks of ripe coffee berries. The wet green beans were fermented for one night and washed to eliminate the mucus, followed by sun-drying for one day until the moisture content attained $\pm 40 \%$. The hulls were then shelled to obtain green coffee. After shelling, the beans were further sun-dried for 5 days until the moisture content attained $\pm 10 \%$.

According to Dharmaputra et al. (2019), polypropylene bag is a type of packaging material used by farmers, collectors, and big traders in Tana Toraja and North Toraja Regencies to store coffee beans. In Makassar, exporters generally use jute bags doubled with polyethylene hermetic bags to store coffee beans.

During storage, coffee beans may be infested by insects, microorganisms, mites, and rats. Among microorganisms, fungi are the most dominant cause of deterioration in stored grains or seeds. Fungal infection in grains can cause discoloration, musty odor, weight loss, reduction in nutritional contents, and mycotoxin contamination.

Ochratoxin A (OTA) contamination in coffee beans becomes a very important subject as some consumer countries have imposed the Maximum Tolerable Limits (MTL) of OTA. BPOM RI (2018) has determined the MTL of OTA in powdered coffee and kopi sangrai (roasted coffee) to be as much as $5 \mathrm{ppb}$, while that in instant coffee to be as much as $10 \mathrm{ppb}$.
In Brazil, the maximum limit allowed for OTA in coffee is $10 \mathrm{ppb}$ (Brazil 2011).

OTA is a potent nephrotoxic mycotoxin that has been linked to kidney problems in both livestock and human populations (Cabañes $e t$ al. 2010). It also has carcinogenic, genotoxic, and immunotoxin properties. OTA has been reported in temperate and tropical countries to naturally occur mainly on cereals and their products. According to Bui-Klimke and $\mathrm{Wu}$ (2015), in tropical regions, OTA is mainly produced by Aspergillus carbonarius, $A$. niger, and A. ochraceus, while in sub-tropical regions it is produced by Penicillium verrucosum.

Dharmaputra et al. (2019) reported that in Tana Toraja Regency, North Toraja Regency, and Makassar Municipality, Indonesia, Penicillium citrinum was the dominant fungus found in coffee beans collected from farmers, collectors, and traders. Meanwhile, $A$. niger wais the dominant fungus found in those beans from the exporters. At trader level, $46 \%$ of the samples were infected by $A$. ochraceus and $A$. niger. At exporter level, $44 \%$ of the samples were infected by $A$. ochraceus, while $78 \%$ of the samples were infected by $A$. niger (Dharmaputra et al. 2019).

Rosavani and Harada (2019) reported that in 2019, nine of ten samples of green coffee beans collected from Argopuro mountain areas, Jember, East Java Province, Indonesia were infected with OTA, in which the highest concentration was $0.4319 \mathrm{ppm}$ and the lowest concentration was $0.0146 \mathrm{ppm}$. Good Handling Processing (GHP) in coffee beans is not only useful in preventing ochratoxigenic fungal growth but also useful in providing good taste and aroma. According to Sunarharum et al. (2018) wet fermentation and controlled mechanical drying were found to yield a better coffee sensory profile than natural and semi-wet fermentation. Other research, Evangelista et al. (2015) explained that Meyerozyma caribbica and Hanseniaspora uvarum were dominant yeasts in coffee beans fermented using wet method from Lavras, Brazil; while Torulaspora delbrueckii was dominant yeast in coffee beans from Monte Carmelo. Tripetch and Borompichaichartkul (2019) reported that high density polyethylene (HDPE) bag was better than a jute sack for green coffee beans for 15 months of storage, because the polyethylene bag has the capability 
of preserving the moisture content, color and chlorogenic acid of the coffee beans.

Postharvest handling methods affect the quality of coffee beans. Consequently, they also affect the price of coffee beans related to foreign trade. The objectives of this study were to: 1 . assess the quality of Arabica coffee beans in terms of moisture content, fungal infection (especially OTA producing fungi), OTA contamination of coffee beans, and the taste of the coffee during storage and 2. recommend appropriate processing methods and the type of packaging materials to ensure the quality of Arabica coffee beans during storage.

\section{MATERIALS AND METHODS}

\section{Source of Green Coffee Beans}

Arabica green coffee beans Grade 1 (grade one) were obtained from CV Frinsa Agrolestari. The coffee was cultivated by a big coffee plantation located in Pangalengan Subdistrict, Bandung Regency, West Java. The coffee plantation has an altitude of $\pm 1,200 \mathrm{~m}$ above sea level. Ripe coffee berries were harvested in one day to obtain a homogenous sample. They were then processed using three different methods, i.e., natural (Fig.1), wet (Fig. 2), and semi-wet methods (Fig. 3).

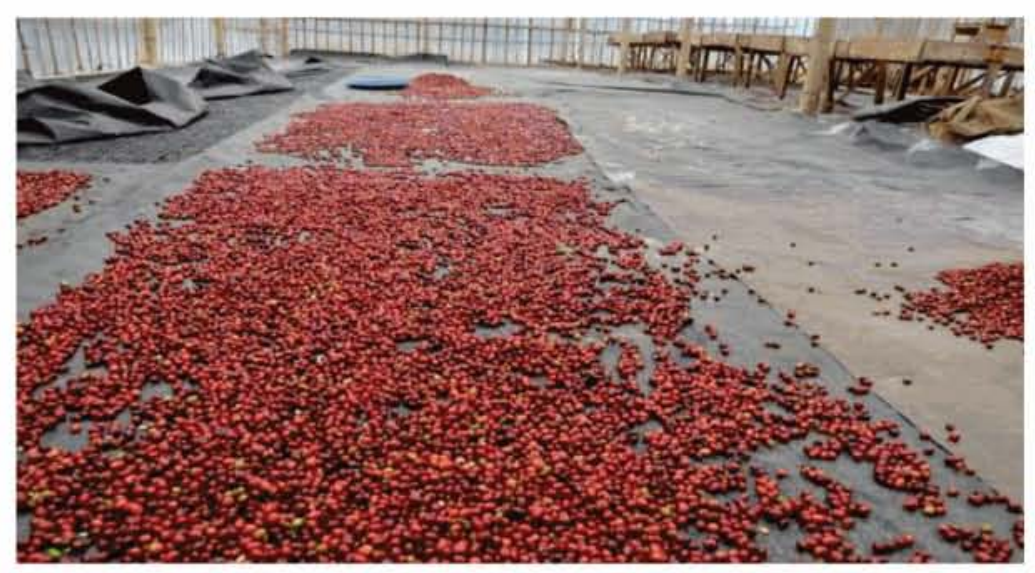

Figure 1 Drying of coffee berries using the natural method

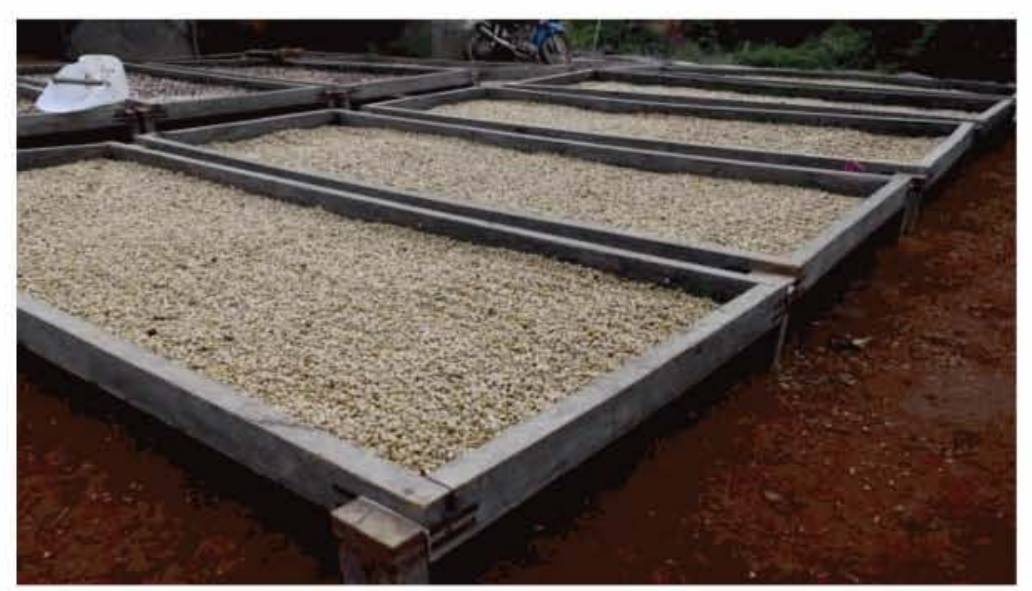

Figure 2 Drying of wet green beans with hulls processed using the wet method 


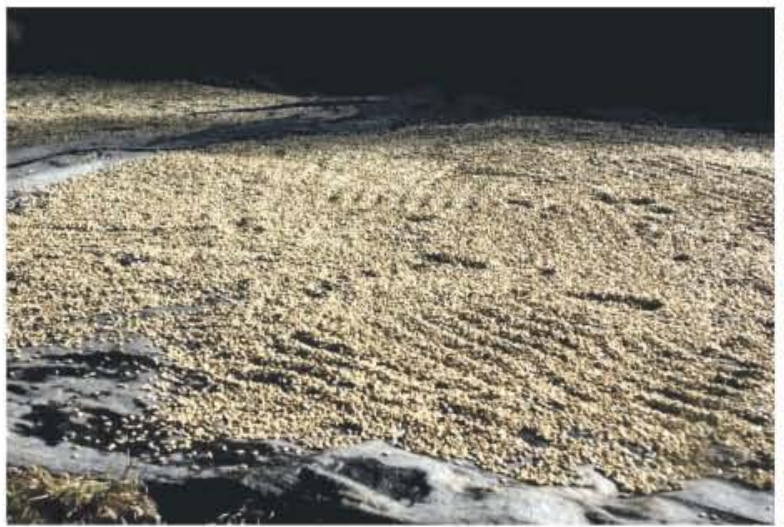

(a)

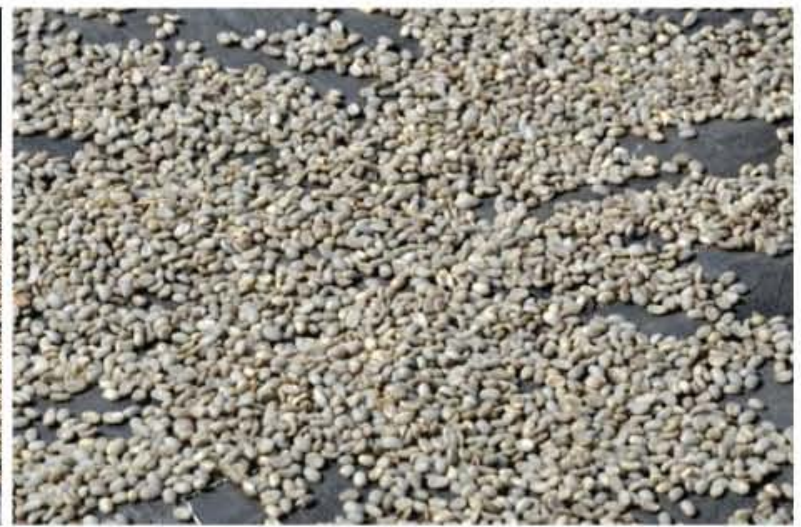

(b)

Figure 3 Drying of wet green beans with hulls (a) and further drying of green beans using the semi-wet method (b)

\section{Packaging and Storing Methods}

Green coffee beans (10\% moisture content) were packed using two types of packaging materials i.e., polypropylene and Kantong Semar high gas barrier bags ( $4 \mathrm{~kg} / \mathrm{bag})$. They were then stored under warehouse conditions for two and four months (Fig. 4). The temperature and relative humidity of the storage were determined using thermo-hygrometer Haar-Synth Hygro.

\section{Sampling Methods}

Samples of coffee beans were subsequently taken from each bag at the beginning, after 2 months, and after 4 months of storage ( $\pm 1 \mathrm{~kg} / \mathrm{bag}$ ). Each sample was then divided three times using a box divider to obtain working samples for moisture content, fungal population and OTA content determinations, and cupping test.

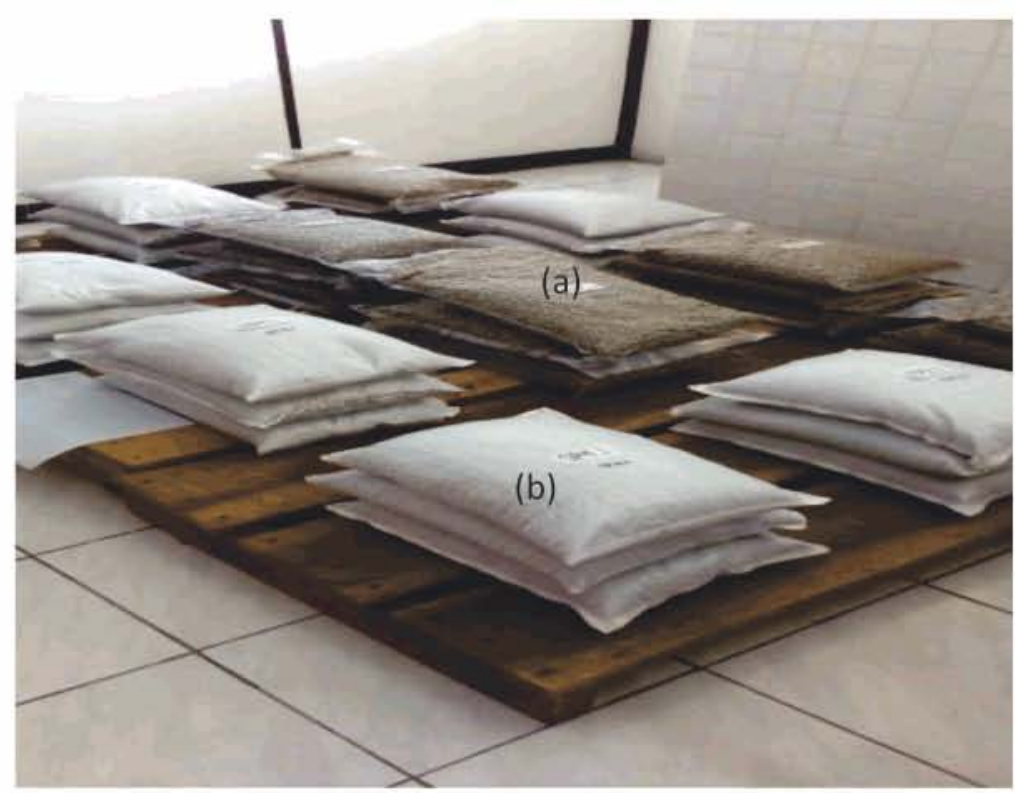

Figure 4 Coffee beans packed in Kantong Semar high gas barrier (a) and polypropylene (b) bags under warehouse conditions 


\section{Determination of Moisture Content, Fungal Population, and OTA Content}

Moisture content of green coffee beans (based on wet basis) was determined using oven method (SNI 2008). Fungi were isolated using a serial dilution method, followed by the pour plate method on Dichloran 18\% Glycerol Agar (DG18) (Pitt \& Hocking 2009). Each fungal population was determined based on the number of fungal colonies on DG18 in a certain dilution factor. Each fungal species was identified using Pitt and Hocking (2009) and Samson et al. (2010) as the main reference. OTA contents were determined using High Performance Liquid Chromatography (HPLC) method (AOAC 2012). Two replicates were used for each sample. Ground coffee was extracted using methanol: 1\% sodium bicarbonate (70:30). Sample extract was diluted using PBS $0.01 \%$ Tween 20 , and it was then eluted using Ochra Test Immunoaffinity Column. Detection was determined using HPLC-FL detector.

\section{Cupping Test}

Cupping test of the samples was based on Standard Cupping Protocol issued by the Coffee Quality Institute and Specialty Coffee Association of America (SCAA 2015). The panelists have a certificate from CQI Q grader. Cupping test was conducted at the Cupping
Test of Coffee Laboratory of PT Kemenady Industri Mandiri, Bogor.

\section{Statistical Analysis}

The data were analyzed using Completely Randomized Factorial Design with three factors. The $1^{\text {st }}, 2^{\text {nd }}$, and $3^{\text {rd }}$ factors were the processing methods, the types of packaging materials, and the duration of storages, respectively. Three replications were implemented for each treatment. Thus, the numbers of unit experiment were $3 \times 2 \times 3 \times 3=54$.

\section{RESULTS AND DISCUSSION}

\section{Moisture Content}

Moisture content of coffee beans resulted from various treatments at the beginning of storage, followed by 2 and 4 months of storage, is presented in Table 1. The range and mean of temperature and relative humidity of the warehouse during storage are presented in Table 2. The moisture content of coffee beans processed using the three methods and packed using polypropylene bags was higher than that of coffee beans packed using Kantong Semar high gas barrier bags. However, it was still lower than the safe moisture content for coffee determined in 2008 by the Indonesian National Standard, i.e., $12.5 \%$.

Table 1 Moisture content of coffee beans resulted from various treatments at the beginning, after 2 months, and after 4 months of storage

\begin{tabular}{lcccccc}
\hline & \multicolumn{5}{c}{ Moisture content (\% wet basis) } \\
\cline { 2 - 6 } \multicolumn{1}{c}{$\begin{array}{c}\text { Processing } \\
\text { method }\end{array}$} & \multicolumn{2}{c}{ 0 month } & \multicolumn{2}{c}{2 months } & \multicolumn{2}{c}{4 months } \\
\cline { 2 - 7 } & $\begin{array}{c}\text { Kemar high } \\
\text { gas barrier }\end{array}$ & $\begin{array}{c}\text { Polypropylene } \\
\text { bag }\end{array}$ & $\begin{array}{c}\text { Kantong } \\
\text { Semar high } \\
\text { gas barrier }\end{array}$ & $\begin{array}{c}\text { Polypropylene } \\
\text { bag }\end{array}$ & $\begin{array}{c}\text { Kantong Semar } \\
\text { high gas } \\
\text { barrier }\end{array}$ & $\begin{array}{c}\text { Polypropylene } \\
\text { bag }\end{array}$ \\
\hline Natural method & $9.5 \mathrm{be}$ & $9.6 \mathrm{bc}$ & $9.8 \mathrm{ca}$ & $10.4 \mathrm{~d}$ & $9.8 \mathrm{c}$ & $11.2 \mathrm{~h}$ \\
Wet method & $8.7 \mathrm{a}$ & $9.2 \mathrm{ef}$ & $8.8 \mathrm{a}$ & $10.3 \mathrm{~d}$ & $8.9 \mathrm{ag}$ & $11.2 \mathrm{~h}$ \\
Semi-wet method & $8.8 \mathrm{ab}$ & $9.6 \mathrm{bc}$ & $9.1 \mathrm{fg}$ & $10.3 \mathrm{~d}$ & $9.2 \mathrm{ef}$ & $11.2 \mathrm{~h}$ \\
\hline
\end{tabular}

Notes: Numbers followed by the same letter do not differ significantly according to Duncan's Multiple Range Test at $95 \%$ confidence level; 0 month $=$ coffee beans at the beginning of storage; 2 months $=$ coffee beans after 2 months of storage; 4 months $=$ coffee beans after 4 months of storage. 
Table 2 Range and mean of temperature and relative humidity in the warehouse for storing coffee beans during storage

\begin{tabular}{ccc}
\hline $\begin{array}{c}\text { Duration of storage } \\
\text { (month) }\end{array}$ & $\begin{array}{c}\text { Range and mean of temperature } \\
\left({ }^{\circ} \mathrm{C}\right)\end{array}$ & $\begin{array}{c}\text { Range and mean of relative humidity } \\
(\%)\end{array}$ \\
\hline $0-2$ & $(24.8-29.3) 28.2 \pm 0.7$ & $(59.0-77.4) 67.8 \pm 4.5$ \\
$2-4$ & $(26.5-29.8) 28.6 \pm 0.7$ & $(60.0-78.3) 69.7 \pm 5.1$ \\
\hline
\end{tabular}

At the beginning of storage, the moisture content of coffee beans processed using the dry method was higher than that of wet and semiwet methods. In the dry processing method, the drying of coffee beans could not reach the maximum drying level because the beans were still protected by the pulp of beans. Aeration inside of polypropylene bags was higher than that of Kantong Semar high gas barrier bags; consequently, the moisture content of coffee beans packed in polypropylene bags was higher than that packed in Kantong Semar high gas barrier bags.

\section{Fungal Population and OTA Content}

The research results showed that Aspergillus ochraceus (OTA producing fungus) was found only in coffee beans processed using dry and wet methods at the beginning of storage. Its population was relatively low, i.e., 1 and $3 \mathrm{cfu} / \mathrm{g}$ w.b (Table 3). The population of $A$. niger (OTA producing fungus) in coffee beans processed using the three different methods was relatively low (< $10 \mathrm{cfu} / \mathrm{g} \mathrm{w} . \mathrm{b})$ (Table 4). The highest population of $A$. niger was found in coffee beans processed using the semi-wet method (Table 3).

Table 3 Fungal population of coffee beans resulted from various treatments at the beginning, after 2 months, and after 4 months of storage

\begin{tabular}{|c|c|c|c|c|}
\hline \multirow{2}{*}{ Treatment } & \multirow{2}{*}{ Fungi } & \multicolumn{3}{|c|}{ Fungal population (cfu/g wet basis) } \\
\hline & & 0 month & 2 months & 4 months \\
\hline \multirow[t]{14}{*}{ FH } & Aspergillus flavus & 0 & 0 & 3 \\
\hline & A. chevalieri & 330 & 3 & 40 \\
\hline & A. niger & 2 & 2 & 1 \\
\hline & A. ochraceus & 1 & 0 & 0 \\
\hline & A. penicillioides & 0 & 0 & 7 \\
\hline & A. tamarii & 0 & 1 & 0 \\
\hline & Cladosporium cladosporioides & 3 & 3 & 3 \\
\hline & Fusarium avenaceum & 8 & 0 & 0 \\
\hline & Fusarium sp. & 0 & 11 & 0 \\
\hline & Penicillium citrinum & 9 & 17 & 3 \\
\hline & Wallemia sebi & 0 & 0 & 11 \\
\hline & Yeast A & 219 & 0 & 38 \\
\hline & Yeast B & 43 & 822 & 0 \\
\hline & Yeast B2 & 0 & 11 & 3 \\
\hline \multirow[t]{10}{*}{$\mathrm{SH}$} & Aspergillus flavus & 0 & 2 & 10 \\
\hline & A. chevalieri & 38 & 7 & 5 \\
\hline & A. niger & 3 & 9 & 4 \\
\hline & A. penicillioides & 0 & 4 & 1 \\
\hline & Cladosporium cladosporioides & 0 & 7 & 1 \\
\hline & Fusarium sp. & 0 & 73 & 0 \\
\hline & Penicillium citrinum & 7 & 7 & 0 \\
\hline & Yeast A & 178 & 0 & 0 \\
\hline & Yeast B & 9 & 115 & 0 \\
\hline & Yeast B2 & 0 & 55 & 2 \\
\hline \multirow[t]{6}{*}{$\mathrm{NH}$} & Aspergillus flavus & 1 & 11 & 2 \\
\hline & A. chevalieri & 19 & 0 & 2 \\
\hline & A. niger & 1 & 1 & 0 \\
\hline & A. ocbraceus & 6 & 0 & 0 \\
\hline & A. penicillioides & 0 & 2 & 1 \\
\hline & A. tamarii & 0 & 9 & 0 \\
\hline
\end{tabular}


Table 3 (Continued)

\begin{tabular}{|c|c|c|c|c|}
\hline \multirow{2}{*}{ Treatment } & \multirow{2}{*}{ Fungi } & \multicolumn{3}{|c|}{ Fungal population (cfu/g wet basis) } \\
\hline & & 0 month & 2 months & 4 months \\
\hline & Cladosporium cladosporioides & 0 & 6 & 4 \\
\hline & Fusarium avenaceum & 7 & 0 & 0 \\
\hline & Penicillium citrinum & 2 & 2 & 3 \\
\hline & Yeast A & 89 & 0 & 0 \\
\hline & Yeast B & 8 & 0 & 0 \\
\hline \multirow[t]{13}{*}{ FP } & Aspergillus flavus & 3 & 0 & 1 \\
\hline & A. chevalieri & 31 & 7 & 10 \\
\hline & A. niger & 3 & 1 & 2 \\
\hline & A. ochraceus & 3 & 1 & 0 \\
\hline & A. penicillioides & 0 & 3 & 0 \\
\hline & A. tamarii & 0 & 1 & 0 \\
\hline & Cladosporium cladosporioides & 0 & 3 & 2 \\
\hline & Fusarium avenaceum & 8 & 0 & 0 \\
\hline & Fusarium sp. & 0 & 7 & 0 \\
\hline & Penicillium citrinum & 22 & 50 & 0 \\
\hline & Yeast A & 584 & 0 & 0 \\
\hline & Yeast B & 562 & 20 & 0 \\
\hline & Yeast D & 39 & 0 & 0 \\
\hline \multirow[t]{9}{*}{ SP } & Aspergillus chevalieri & 17 & 2 & 2 \\
\hline & A. niger & 0 & 2 & 3 \\
\hline & A. penicillioides & 0 & 4 & 0 \\
\hline & Cladosporium cladosporioides & 1 & 8 & 2 \\
\hline & Penicillium citrinum & 1 & 0 & 1 \\
\hline & Yeast A & 112 & 0 & 0 \\
\hline & Yeast B & 30 & 24 & 0 \\
\hline & Yeast B2 & 0 & 1 & 0 \\
\hline & Yeast D & 300 & 0 & 0 \\
\hline \multirow[t]{11}{*}{ NP } & Aspergillus flavus & 1 & 7 & 0 \\
\hline & A. chevalieri & 11 & 0 & 3 \\
\hline & A. niger & 0 & 1 & 2 \\
\hline & A. penicillioides & 0 & 7 & 0 \\
\hline & A. tamarii & 0 & 7 & 0 \\
\hline & Cladosporium cladosporioides & 0 & 9 & 2 \\
\hline & Fusarium avenaceum & 1 & 0 & 0 \\
\hline & Penicillium citrinum & 7 & 1 & 0 \\
\hline & Yeast A & 152 & 0 & 0 \\
\hline & Yeast B & 8 & 0 & 0 \\
\hline & Yeast D & 12 & 0 & 0 \\
\hline
\end{tabular}

Notes: $\mathrm{N}=$ coffee beans processed using the natural method; $\mathrm{F}=$ coffee beans processed using the wet method; $\mathrm{S}=$ coffee beans processed using the semi-wet method; $\mathrm{H}=$ coffee beans packed in Kantong Semar high gas barrier bags; $\mathrm{P}=$ coffee beans packed in polypropylene bags.

Table 4 Population of $A$. niger in coffee beans resulted from various processing methods

\begin{tabular}{lc}
\hline \multicolumn{1}{c}{ Processing method } & Population of $A$. niger (cfu/g wet basis) \\
\hline Natural method & $1(1-2) \mathrm{b}$ \\
Wet method & $2(1-3) \mathrm{ab}$ \\
Semi-wet method & $4(2-9) \mathrm{a}$ \\
\hline
\end{tabular}

Note: Numbers followed by the same letter do not differ significantly according to Duncan's Multiple Range Test at $95 \%$ confidence level. 
According to Pitt et al. (2000), OTA is mainly produced by Aspergillus carbonarius, A. niger, and A. ochraceus in tropical regions, while in subtropical regions it is produced by Penicillium verrucosum and $P$. nordicum.

Batista et al. (2009) reported that genus of Aspergillus Section Circumdati and Section Nigri were found in coffee berries and and green beans when they were harvested and during processing. Aspergillus section Circumdati was found in coffee berries and green beans, i.e., $80 \%$ and $41 \%$, respectively, but their population decreased after the first stage of processing. As many as $33 \%$ of 12 samples of coffee beans processed using the wet method was contaminated by Aspergillus section Circumdati. As much as $73 \%$ Aspergillus section Nigri was found in coffee berries and $25 \%$ of it was found in the processed coffee beans.

de Fatima et al. (2013) reported a number of fungi were isolated from 30 samples of Arabica coffee. As many as 20 samples of coffee beans were collected by using conventional cultivation system, and 10 samples were collected by using organic cultivation system. As many as 480 filamentous fungal species were isolated. They belong to genus Aspergillus, group Circumdati, and Nigri. OTA producing fungi isolated were $A$. auricoumus, $A$. ochraceus, $A$. ostianus, $A$. niger, and agregate of $A$. niger. The most frequent OTA producing fungi species was $A$. ochraceus which corresponded to $89.55 \%$ of samples.

OTA contents in all samples during storage were lower than the detection limit of the instrument $(<1.85 \mathrm{ppb})$. Samples were dominated by yeast at the beginning of storage. Its population was $1.9 \times 10^{2}-1.2 \times 10^{3} \mathrm{cfu} / \mathrm{g}$ w.b (Table 5). It was assumed that the yeast inhibited the growth of OTA producing fungi; consequently, it prevented OTA production. According to Masoud et al. (2005), volatile compounds such as ethyl acetate, isobutyl acetate, 2-phenyl ethyl acetate, ethyl propionate, and isoamyl alcohol which are produced during coffee processing by Pichia anomala, P. kliyvveri, and Hanseniaspora uvarum, inhibited OTA producing fungi $(A$. ochraceus $)$ and prevented the OTA production.

The total of yeast population decreased during storage (Table 5). It was assumed that yeast competed with filamentous fungi. Filamentous fungi (except $A$. niger and A. ochraceus) were isolated from coffee beans, i.e., A. flavus, A. chevalieri, A. penicillioides, A. tamarii, Cladosporium cladosporioides, Fusarium avenaceum, Fusarium sp., Penicillium citrinum, Wallemia sebi (Table 3). Munyendo et al. (2017) reported that fungal infection in coffee beans processed using the dry method was higher than that processed using the wet method.

Table 5 Total yeast population of coffee beans resulted from various treatments

\begin{tabular}{|c|c|c|c|c|c|c|}
\hline \multirow[b]{3}{*}{ Processing method } & \multicolumn{6}{|c|}{ Total population of yeast (cfu/g wet basis) } \\
\hline & \multicolumn{2}{|c|}{0 month } & \multicolumn{2}{|c|}{2 months } & \multicolumn{2}{|c|}{4 months } \\
\hline & $\begin{array}{c}\text { Kantong Semar } \\
\text { high } \\
\text { gas barrier }\end{array}$ & $\begin{array}{c}\text { Polypropylene } \\
\text { bag }\end{array}$ & $\begin{array}{c}\text { Kantong Semar } \\
\text { high gas } \\
\text { barrier }\end{array}$ & $\begin{array}{c}\text { Polypropylene } \\
\text { bag }\end{array}$ & $\begin{array}{c}\text { Kantong Semar } \\
\text { high gas } \\
\text { barrier }\end{array}$ & $\begin{array}{c}\text { Polypropylene } \\
\text { bag }\end{array}$ \\
\hline Natural method & $\begin{array}{c}97 \\
(30-174) \text { abcd }\end{array}$ & $\begin{array}{c}152 \\
(40-370) \text { abcd }\end{array}$ & $0 \mathrm{f}$ & $0 \mathrm{f}$ & $0 \mathrm{f}$ & $0 \mathrm{f}$ \\
\hline Wet method & $\begin{array}{c}262 \\
(33-533) a\end{array}$ & $\begin{array}{c}1185 \\
(397-1,683) \text { abcd }\end{array}$ & $\begin{array}{c}534 \\
(213-1,143) a b\end{array}$ & $\begin{array}{c}24 \\
(3-60) \text { def }\end{array}$ & $\begin{array}{c}39 \\
(10-57) \text { bcd }\end{array}$ & $0 \mathrm{f}$ \\
\hline Semi-wet method & $\begin{array}{c}187 \\
(120-283) \text { abcd }\end{array}$ & $\begin{array}{c}442 \\
(136-986) \mathrm{abc}\end{array}$ & $\begin{array}{c}170 \\
(40-387) \mathrm{abcd}\end{array}$ & $\begin{array}{c}25 \\
(17-37) \text { cde }\end{array}$ & $\begin{array}{c}2 \\
(0-7) \text { ef }\end{array}$ & $0 \mathrm{f}$ \\
\hline
\end{tabular}

Note: Numbers followed by the same letter do not differ significantly according to Duncan's Multiple Range Test at 95\% confidence level. 


\section{Cupping Test}

Specialty coffee beans are not accepted when the cupping test score is lower than 80 (SCAA 2015). According to Atmawinata (2002), in general, coffee is not consumed because of its nutritional value, but because of the flavor and physiological influences causing people to stay awake, have improved moods, feel fresh, have less fatigue condition, and to feel enthusiatic. Saepudin (2005) reported that the value of coffee beans is not only determined by physical quality but also by the value of the flavor. Therefore, cupping test is one of the methods to determine the quality of coffee in importing countries.

The qualification of coffee beans based on the cupping test final scores was divided into 4 categories, i.e., outstanding $(90$ - 100), excellent $(85-89.99)$, very good $(80-84.99)$, and below specialty quality (below 80) (SCAA 2015). Coffee beans with outstanding, excellent, and very good categories with the final score of 80 100 belong to specialty qualification. On the contrary, coffee beans with below specialty category do not belong to specialty qualification, but they may still properly be consumed. According to the panelists, coffee beans could not be consumed when the final score was $\leq 30$.
The flavor of coffee beans handled using the three processing methods which were then packed in Kantong Semar high gas barrier bags and polypropylene bags and stored for 4 months was still above the total score of specialty grade $\geq 80$ (Table 6 ). The highest total score was obtained by the coffee beans processed with the natural processing method which were then packed in Kantong Semar high gas barrier bags (84). Borem et al. (2013) reported that Kantong Semar high gas barrier bags are also impermeable to water and gases including $\mathrm{CO}_{2}, \mathrm{O}_{2}$, and $\mathrm{N}_{2}$. Ribeiro et al. (2011) explained that hermetic bags are able to maintain the sensory qualities of materials, such as volatile compounds, textures, and colors. It is suitable for certain products requiring the manipulation of atmospheric conditions. Therefore, Kantong Semar high gas barrier bags are able to maintain the sensory quality, especially the aroma of packaged material.

Murthy and Naidu (2011) found that the taste of coffee beans processed by using the wet processing method was better than that processed by using the dry processing method because the aroma of volatile taste in roasting of coffee beans processed using the wet method was better than those processed using the dry method.

Table 6 Results of cupping test of coffee beans processed by various treatments after 2 and 4 months of storage

\begin{tabular}{|c|c|c|c|c|c|c|c|c|c|c|c|c|}
\hline \multirow{3}{*}{ Attribute } & \multicolumn{12}{|c|}{ Score } \\
\hline & \multicolumn{2}{|c|}{$\mathrm{FH}$} & \multicolumn{2}{|c|}{ FP } & \multicolumn{2}{|c|}{ SH } & \multicolumn{2}{|c|}{ SP } & \multicolumn{2}{|c|}{$\mathrm{NH}$} & \multicolumn{2}{|c|}{ NP } \\
\hline & $2 \mathrm{mnt}$ & $4 \mathrm{mnt}$ & $2 \mathrm{mnt}$ & $4 \mathrm{mnt}$ & $2 \mathrm{mnt}$ & $4 \mathrm{mnt}$ & $2 \mathrm{mnt}$ & $4 \mathrm{mnt}$ & $2 \mathrm{mnt}$ & $4 \mathrm{mnt}$ & $2 \mathrm{mnt}$ & $4 \mathrm{mnt}$ \\
\hline Fragrance & 7.75 & 7.5 & 7.75 & 7.75 & 7.5 & 7.5 & 7.5 & 7.5 & 7.75 & 7.75 & 7.5 & 7.5 \\
\hline Flavor & 7.5 & 7.5 & 7.5 & 7.5 & 7.5 & 7.5 & 7.5 & 7.25 & 8 & 7.75 & 7.75 & 7.75 \\
\hline Aftertaste & 7.25 & 7.25 & 7.5 & 7.5 & 7.5 & 7.5 & 7.5 & 7.5 & 7.75 & 7.75 & 7.5 & 7.5 \\
\hline Acidity & 7.75 & 7.5 & 7.75 & 7.75 & 7.75 & 7.5 & 7.5 & 7.25 & 7.75 & 7.75 & 7.75 & 7.75 \\
\hline Body & 7.75 & 7.75 & 7.75 & 7.75 & 7.5 & 7.5 & 7.5 & 7.5 & 7.5 & 7.5 & 7.5 & 7.5 \\
\hline Balance & 7.5 & 7.5 & 7.75 & 7.75 & 7.5 & 7.5 & 7.5 & 7.5 & 7.75 & 7.75 & 7.5 & 7.5 \\
\hline Uniformity & 10 & 10 & 10 & 10 & 10 & 10 & 10 & 10 & 10 & 10 & 10 & 10 \\
\hline Clean Cup & 10 & 10 & 10 & 10 & 10 & 10 & 10 & 10 & 10 & 10 & 10 & 10 \\
\hline Sweetness & 10 & 10 & 10 & 10 & 10 & 10 & 10 & 10 & 10 & 10 & 10 & 10 \\
\hline Overall & 7.75 & 7.5 & 7.5 & 7.5 & 7.5 & 7.5 & 7.5 & 7.5 & 7.5 & 7.5 & 7.5 & 7.5 \\
\hline Total score & 83.25 & 82.5 & 83.5 & 83.5 & 82.75 & 82.5 & 82.5 & 82.5 & 84 & 83.75 & 83 & 83 \\
\hline Defect & 0 & 0 & 0 & 0 & 0 & 0 & 0 & 0 & 0 & 0 & 0 & 0 \\
\hline Final score & 83.25 & 82.5 & 83.5 & 83.5 & 82.75 & 82.5 & 82.5 & 82.5 & 84 & 83.75 & 83 & 83 \\
\hline
\end{tabular}

Notes: Laboratory of cupping test: PT Kemenady Industri Mandiri, Bogor; $0=$ Not present; $1=$ unacceptable; $2=$ very poor; $3=$ poor; $4=$ fair; $5=$ average; $6=$ good; $7=$ very good; $8=$ excellent; $9=$ outstanding; 10 = exceptional; Specialty grade $\geq 80 ; \mathrm{FH}=$ full wash (wet method) using Kantong Semar high gas barrier bag; FP = full wash (wet method) using polyprophylene bag; $\mathrm{SH}=$ semi-wet method using Kantong Semar high gas barrier bag; $\mathrm{SP}=$ semi-wet method using polyprophylene bag; $\mathrm{NH}=$ natural method using Kantong Semar high gas barrier bag; NP = natural method using polyprophylene bag. 


\section{CONCLUSION}

Moisture content of coffee beans processed using the three processing methods and then packed using polypropylene bags was higher than those packed using Kantong Semar high gas barrier bags. However, the moisture content was still lower than the safe moisture content for coffee determined by the Indonesian National Standard (12.5\%). Aspergillus niger (OTA producing fungus) was found in coffee beans processed by using the three processing methods and packed using Kantong Semar high gas barrier bags. The fungal population was relatively low ( $<0.1 \times 10 \mathrm{cfu} / \mathrm{g}$ wet basis). Aspergillus ochraceus (OTA producing fungus) was found in coffee beans processed by using dry and wet methods at the beginning of the storage. The fungal population was also relatively low (<0.3 x $10 \mathrm{cfu} / \mathrm{g}$ w.b). OTA content was not detected in all coffee samples, because it was lower than the detection limit of the instrument used $(<1.85 \mathrm{ppb})$. At the beginning of storage, all coffee samples were dominated by yeast with the population of $1.9 \mathrm{x}$ $10^{2}-1.2 \times 10^{3} \mathrm{cfu} / \mathrm{g}$ w.b. The taste of coffee in various treatments during the 4 months of storage was still above the total standard cupping test score for specialty grade $\geq 80$. The highest total score (84) was found in coffee beans processed by using the dry processing method and packed in Kantong Semar high gas barrier bags. The three processing methods and the two types of packaging materials can be used to maintain the quality of coffee beans during 4 months of storage. Future research concerning the use of other types of packaging materials is needed.

\section{ACKNOWLEDGEMENTS}

The authors would like to acknowledge SEAMEO BIOTROP for providing financial support through Daftar Isian Pelaksanaan Anggaran (DIPA) 2017. Special gratitude goes to Mr Tony Kristianto Juwono from PT Multi Panelindo Margawi, Semarang for allowing us using the Kantong Semar high gas barrier bags in our study. Thanks are also due to CV Frinsa
Agrolestari and PT Kemenady Industri Mandiri for their assistance during the research.

\section{REFERENCES}

AOAC Official Method 2004.10. 2012. Ochratoxin A in green coffee. 19 th $^{\text {th }}$ (ed.). In: Latimer GW, editor. Official Methods of Analysis of AOAC International, Gaithersburg (US): AOAC International. Vol II, Chapter 49:67-9.

Atmawinata O. 2002. Peranan uji citarasa dalam pengendalian mutu kopi [The role of cupping test in controlling the quality of coffee]. Lecture note presented in Training on Cupping Test of Coffee. Jember (ID): Indonesian Research Institute of Coffee and Cacao.

Badan Pengawas Obat dan Makanan [BPOM]. 2018. Peraturan Badan POM Nomor 8 Tahun 2018 tentang batas maksimum cemaran kimia dalam pangan olahan [Regulation of the Head of the Indonesian Agency for Food and Drug Control Number 8 of 2018 concerning chemical contamination in processed food]. Jakarta (ID): Badan POM Republik Indonesia.

Batista LR, SM Chalfoun, CF Silva, M Cirillo, EA Varga, RF Schwan. 2009. Ochratoxin A in coffee beans (Coffea arabica L.) processed by dry and wet methods. Food control 20:784-90.

Borem FM, Riberio FC, Figueiredo LP, Giomo GS, Fortunato VA, Isquerdo EP. 2013. Evaluation of the sensory and color quality of coffee beans stored in hermetic_packaging. J Stored Product Res 52:1-6.

Brazil. 2011. Rules on maximum permitted limits for mycotoxins in foods and beverages. Resolution RDC No. 7 of February 18, 2011. Brasilia (BR): Brazilian Ministry of Health.

Bui-Klimke TR, Wu F. 2015. Ochratoxin A and human health risk: A review of the evidence. Crit Rev Food Sci Nutr 55(13):1860-9. Doi: 10.1080/ 10408398.2012.724480

Cabañee FJ, Bragulat MA, Castella G. 2010. Ochratoxin A producing species in the genus Penicillium. Toxins 2:1111-20. Doi: $10.3390 /$ toxins 2051111

Dharmaputra OS, Ambarwati S, Retnowati I, Nurfadila N. 2019. Fungal infection of stored Arabica coffee (Coffea arabica) beans in Tana Toraja Regency, South Sulawesi Province, Indonesia. BIOTROPIA 26(2):127-35.

de Fatima RE, Borges JG, Cirillo MA, Prado G, Paiva LC, Batista LR. 2013. Ochratoxigenic fungi associated with green coffee beans (Coffea arabica L.) in conventional and organic cultivation in Brazil. Braz J Microbiol 44 (2):377-84. doi: 10.1590/5151783822013000200006 .

Evangelista SR, da Cruz Pedroso Miguel MG, Silva CF, Pinheiro ACM, Schwan RF. 2015. Microbiological 
diversity associated with the spontaneous wet method of coffee fermentation. International Journal of Food Microbiology 210:102-112.

Gabungan Eksportir Kopi Indonesia [GAEKI]. 2018. Areal dan produksi kopi [Areal and coffee production. Jakarta (ID): GAEKI; [cited 2018 Oct 31]. Available from: http: //gaeki.or.id/areal-danproduksi.

Kementerian Pertanian Republik Indonesia. 2012. Peraturan Menteri Pertanian RI nomor 52/Permentan/OT.140/9/2012, tanggal 4 September 2012 tentang Pedoman Penanganan Pascapanen Kopi [Regulation of the Ministry of Agriculture, the Republic of Indonesia number OT.140/9/2012 concerning Guidelines of Coffee Postharvest Handling]. Jakarta (ID): Kementerian Pertanian Republik Indonesia. [cited 2019 Nov 13 ] Available from: ditjenpp.kemenkumham.go.id/ arsip/bn/2012/bn909-2012lamp.pdf

Masoud W, Poll L, Jakobsen M. 2005. Influence of volatile compounds produced by yeasts predominant during processing of Coffea arabica in East Africa on growth and ochratoxin A (OTA) production by Aspergillus ochraceus. Yeast: 22: 1133-42.

Munyendo LM, Koskei R, Mburu M [Internet]. 2017. Molds and ochratoxin A associated with green coffee (Coffea arabica) beans processed by dry and wet methods in Nyeri Country. IOSR Journal of Environmental Science, Toxicology and Food Technology (IOSR-JESTFT) e- ISSN: 2319-2402, p-ISSN: 2319-2399, Vol 11, Issue 6 Ver. I June 2017), pp. 66-72. [cited 2017 Oct 15]. Available from www.iosrjournals.org. doi: 10.9790/24021106016672

Murthy, PS, Naidu MM. 2011. Improvement of Robusta coffee fermentation with microbial enzymes, European Appl Sci 3(4):130-9.

Pitt JI, Basilico JC, Abarca ML, Lopez C. 2000. Mycotoxins and toxigenic fungi. Medical Mycol 38:41-6.

Pitt JI, Hocking AD. 2009. Fungi and food spoilage. (3 ${ }^{\text {rd }}$ ed.). New York (US): Springer.
Ribeiro FC, Borem FM, Giomo GS, Lima RRD, Malta MR, Figueiredo LP. 2011. Storage of green coffee in hermetic packaging injected with CO2. J Stored Product Res 47:341-8.

Rosavani MA, Harada H. 2019. Presence of ochratoxin in a green coffee beans processed naturally by smallholder farmers in Jember. Novel Techniques in Nutrition and Food Sci 9(3):270-1.

Saepudin A. 2005. Evaluasi faktor-faktor yang mempengaruhi citarasa kopi Arabika dengan menggunakan Manova dan analisis profil. (Studi kasus: hasil uji citarasa kopi Arabika Kintamani tahun 2004). [Skripsi]. Bogor (ID): Fakultas Matematika dan Ilmu Pengetahuan Alam IPB. Available from http://repository.ipb.ac.id/handle/ $123456789 / 12968$

Samson RA, Houbraken J, Thrane U, Frisvad JC, Andersen B. 2010. Food and indoor fungi. CBS Laboratory Manual Series. Utrecht (NL): CBSKNAW Fungal Biodiversity Centre.

SCAA. 2015. SCAA Protocols; Cupping Specialty Coffee. Specialty Coffee Association of America. [cited 2017 Nov 16]. Available from https:// www.scaa.org/PDF/resources/cupping-protocols.pdf

Standar Nasional Indonesia. 2008. Biji kopi [Coffee beans]. Jakarta (ID): Badan Standardisasi Nasional.

Sunarharum WB, Yuwono SS, Nadhiroh H. 2018. Effect of different post-harvest processing on the sensory profile of Java Arabica coffee. Advances in Food Science, Sustainable Agriculture and Agroindustrial Engineering 1(1):9-13.

Tripetch P, Borompichaichartkul C. 2019. Effect of packaging materials and storage time on changes of colour, phenolic content, chlorogenic acid and antioxidant activity in Arabica green coffee beans (Coffea arabica L. cv. Catimor). Journal of Stored Products Research 84:101510.

Walton JX [Internet] 2018. Countries produce most coffee. New York (US): Investopedia; [updated 2019 Feb 09; cited 2018 Oct 31]. Available from https://www.investopedia.com/articles/investing. 